\title{
Duodenum and Ampulla of Vater Neuroendocrine Tumor cM1 TNM Finding v8
}

National Cancer Institute

\section{Source}

National Cancer Institute. Duodenum and Ampulla of Vater Neuroendocrine Tumor CM1

TNM Finding v8. NCI Thesaurus. Code C135054.

Duodenum and ampulla of Vater neuroendocrine tumor with distant metastasis. (from AJCC 8th Ed.) 